\title{
Study on Heat Treatment Procedure of Aluminum Alloy Castings and Flue Gas Waste Heat Recovery Technology
}

\author{
Qian Huiguo ${ }^{1, a}, \quad$ Luo Xionghui ${ }^{1, b}$, Chen jingson ${ }^{2, c}$ \\ ${ }^{1}$ Shanghai Institute of Technology, Shanghai 201418, China \\ ${ }^{2}$ SHEOI Industrial Combustion Equipment (Shanghai) Co., Ltd. \\ aqianhg@sit.edu.cn, b1796821019@qq.com, c2012931038@qq.com
}

Key words: Heat treatment procedure, solid smelting oven, aging oven, drying oven, energy conservation and emission reduction, waste heat recovery

\begin{abstract}
This paper introduces the status quo of current heat treatment procedure of aluminum alloy castings, Heat treatment furnace burner uses cold air as a fuel and the resulting emissions are directly discharged to the atmosphere instead of being recovered, so a great number of residual heat resources are wasted. Therefore, the basic principle - waste gas heat utilization is proposed, but equipment operation synchronous rate, utilization of system equipment and one-time full recovery shall be considered, finally, "heat supply of aging oven" is selected according to actual situation of this project. The cut-and-try heat balance method is applied to calculate the consumption of natural gas in each furnace per hour and energy economic ratio after waste heat recovery, produces the obvious energy saving effect and high investment value and guides and demonstrates the energy saving transformation of heat treatment procedure of aluminum alloy castings.
\end{abstract}

\section{Introduction}

In recent years, with the rapid development of China's industry, energy consumption has been increasing dramatically while the contradiction between the energy and the environment is becoming increasingly prominent and sharp, so strengthening the recovery and utilization of residual heat and energy is the inevitable choice for constructing resource- saving and environment-friendly society and is the only way to promote energy conservation and emissions reduction and transform the mode of growth ${ }^{[1]}$.

\section{Status Quo of Heat Treatment Procedure of Aluminum Alloy Castings}

The heat treatment of aluminum alloy castings can only be executed by two procedures - solid melt and aging (or drying) which are respectively equipped with the corresponding heating oven. The layout of heat treatment equipment is shown as follows:

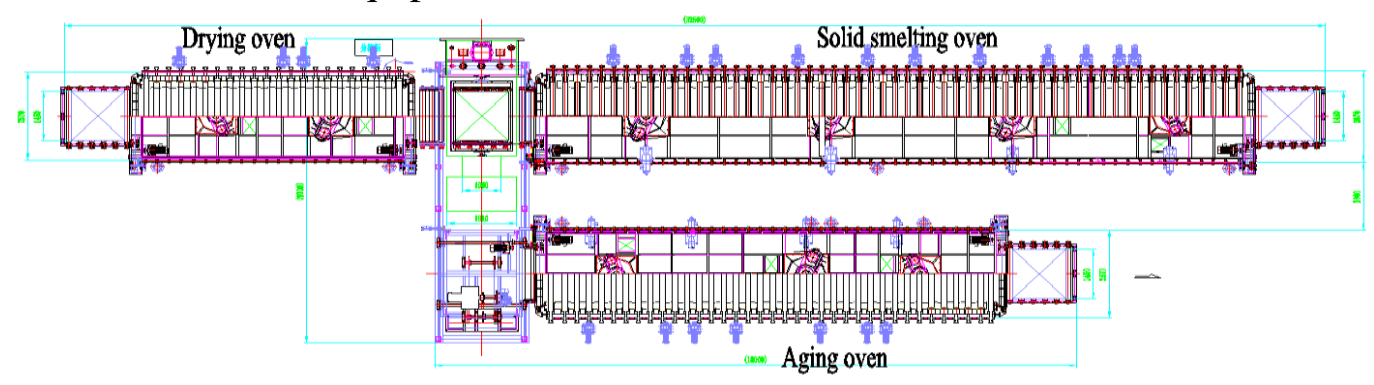

Figure 1 Layout of heat treatment equipment of aluminum alloy castings 
Design parameters of equipment with annual production capacity of 500000 aluminum alloy components: The solid smelting oven is configured with one burner with maximum heating capacity of $8.36 \times 10^{5} \mathrm{~kJ} / \mathrm{hr}$ and three burners with maximum heating capacity of $4.18 \times 10^{5} \mathrm{~kJ} / \mathrm{hr}$, aging oven is configured with three burners with maximum heating capacity of $2.09 \times 10^{5} \mathrm{~kJ} / \mathrm{hr}$ and drying oven is configured with two burners with maximum heating capacity of $2.09 \times 10^{5} \mathrm{~kJ} / \mathrm{hr}^{[2]}$.

Operating state of ovens in the current heat treatment procedure: Heat treatment furnace burner uses cold air as a fuel and the resulting emissions are directly discharged to the atmosphere instead of being recovered, so a great number of residual heat resources are wasted.

\section{Waste Gas Heat Recovery Method of Sold Smelting Oven}

The heat treatment of aluminum alloy castings can only be executed by two procedures - solid melt and aging (or drying). The related heat treatment process and parameters are shown as follows $^{[2]}$ :

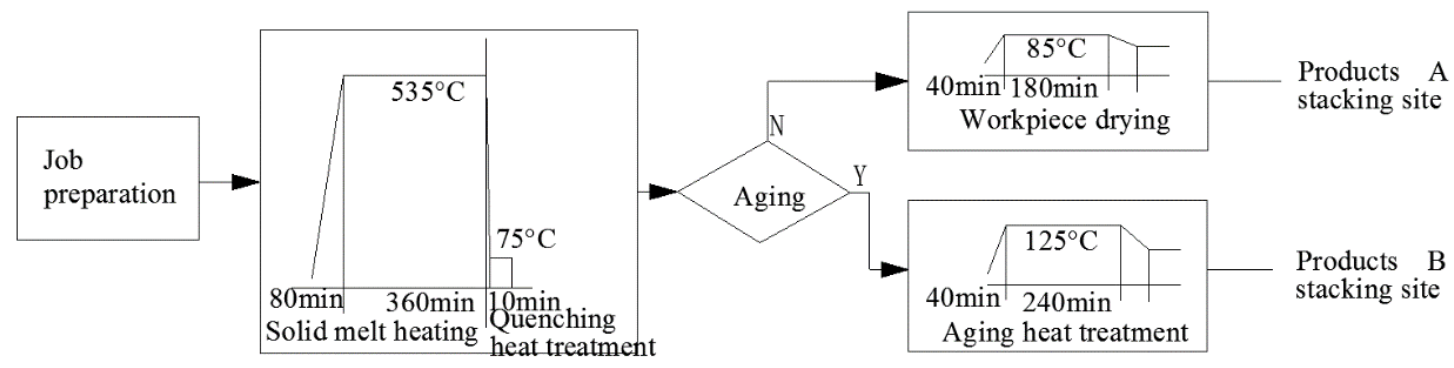

Figure 2 Process flow diagram of heat treatment of aluminum alloy castings

The waste gas discharged from solid smelting oven during heat treatment is up to the temperature of about $535^{\circ} \mathrm{C}$, so it shall be recycled to save energy and reduce emission of the system.

\section{Waste heat recovery plan}

The principle of waste gas heat utilization shall consider equipment operation synchronous rate, utilization of system equipment and one-time full recovery: High equipment operation synchronous rate is required. When main equipment starts to produce, the related waste heat utilization equipment shall run at the same time to reach "cooperation" and maximize waste heat utilization in time domain. The resulting waste heat is firstly used by waste heat materials, is then used to preheat combustion air and finally is used for heating domestic water. The advantages and disadvantages of this waste heat recovery plan are shown as follows: 
Table 1 Advantages and disadvantages of this waste heat recovery plan

\begin{tabular}{|c|c|c|}
\hline $\begin{array}{c}\text { Waste Heat } \\
\text { Recovery Plan }\end{array}$ & \multicolumn{1}{c|}{ Advantages } & \multicolumn{1}{c|}{ Disadvantages } \\
\hline $\begin{array}{c}\text { Preheating } \\
\text { materials }\end{array}$ & $\begin{array}{l}\text { High time synchronization rate; } \\
\text { Waste gas heat is directly used to preheat } \\
\text { materials with high recovery efficiency. }\end{array}$ & $\begin{array}{l}\text { The base area is added; } \\
\text { reconstruction area shall be } \\
\text { poured again as a whole or } \\
\text { strengthened entirely. } \\
\text { Material preheating recovery } \\
\text { section is added. }\end{array}$ \\
\hline $\begin{array}{c}\text { Heat supply } \\
\text { of aging } \\
\text { oven }\end{array}$ & $\begin{array}{l}\text { The recovery equipment is relatively } \\
\text { smelting oven is only brought into natural } \\
\text { gas combustion chamber of aging oven } \\
\text { through insulation flue to replace heat supply } \\
\text { of natural gas. Waste gas heat quantity shall } \\
\text { basically match with heat quantity of aging } \\
\text { oven to have good recovery effect. }\end{array}$ & $\begin{array}{l}\text { Due to inadequate heat supply } \\
\text { recovery device and } \\
\text { requirements of temperature } \\
\text { control accuracy, heat supply } \\
\text { system of natural gas shall be } \\
\text { kept. }\end{array}$ \\
\hline $\begin{array}{c}\text { Heat supply } \\
\text { of drying } \\
\text { oven }\end{array}$ & $\begin{array}{l}\text { The principle is the same as above. Waste } \\
\text { gas emitted from solid smelting oven is } \\
\text { brought into natural gas combustion chamber } \\
\text { of drying oven through insulation flue to } \\
\text { replace heat supply of natural gas. }\end{array}$ & $\begin{array}{c}\text { The waste heat is excess, so it } \\
\text { can be further recycled. For } \\
\text { example, recovery device of hot } \\
\text { water tank can be added. }\end{array}$ \\
\hline $\begin{array}{c}\text { With simple structure, heat exchanger shall } \\
\text { tank }\end{array}$ & $\begin{array}{l}\text { We installed in the former flue to provide } \\
\text { domestic hot water for employees. }\end{array}$ & $\begin{array}{l}\text { Due to low synchronization } \\
\text { rate and application of hot } \\
\text { water, hot water tank which } \\
\text { meets the corresponding } \\
\text { requirements shall be installed. }\end{array}$ \\
\hline
\end{tabular}

The waste heat utilization in the heat treatment procedure shall be considered based on technological characteristics and actual site. There is no extra site area in the former aluminum alloy castings workshop to install the waste heat recovery section, so structural transformation can only be executed in the former space to recover waste heat. Meanwhile, waste gas heat shall be recovered at once to reduce the recovery device. Therefore, "heat supply of aging oven" in the table 1 is selected. The related process is shown as follows:

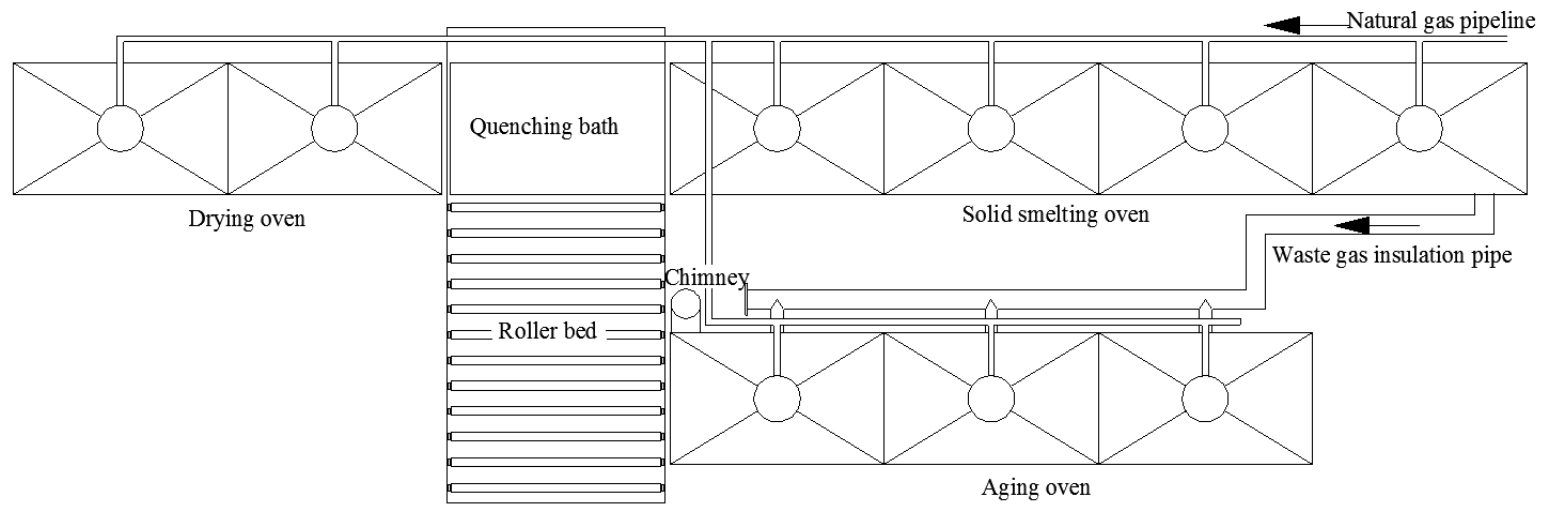

Figure 3 Process flow diagram of waste gas heat recovery 


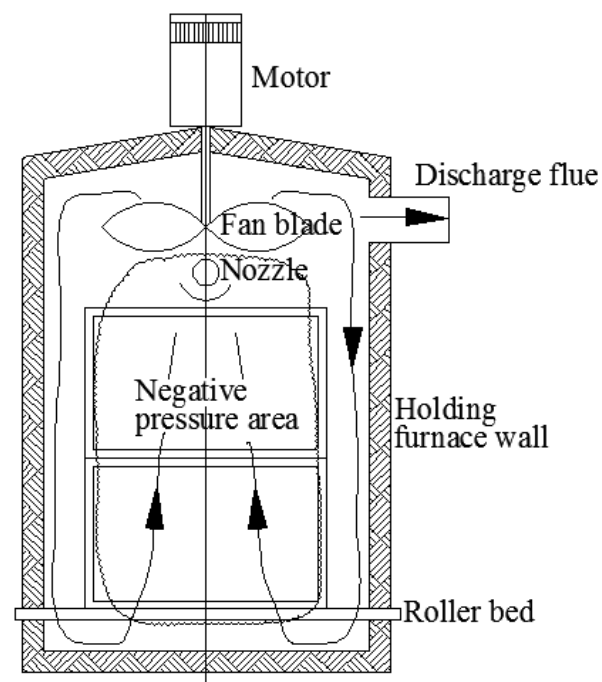

Figure 4 Air flow in the furnace which operates under negative pressure

Adjust the operation mode of solid smelting oven from the former operation under positive pressure to operation under negative pressure. That is, by way of suction, the fan on the furnace top directly delivers waste gas in the furnace to combustion chambers of aging oven from furnace top under positive pressure through pipeline when there is air under negative pressure in the material area, thus providing heat for aging oven and reducing flue ventilator. In addition, gas flowing pattern in the furnace which operates under negative pressure can provide the longer mixing time to facilitate the homogeneity of circulatory flue gas temperature in the material area of furnace and improve the heating quality of materials, but exhaust gas temperature is the highest because waste gas which is mixed after burning directly enters into smoke vent.

Aging oven mainly deals with waste gas from solid smelting oven and retains the former way that it shall be supplemented by head supply of natural gas. The waste heat from solid smelting oven shall be firstly used for heat supply of aging oven. When waste heat is inadequate, natural gas auxiliary heating system of aging oven shall be opened to guarantee the heating of aging oven.

\section{Calculation of gas consumption in the heat treatment procedure of aluminum alloy}

The natural gas consumption of solid smelting oven (or aging oven) is calculated by cut-and-try heat balance method. That is, under the normal operating condition, natural gas consumption is adjusted to calculate the heat input and heat output of solid smelting oven (aging oven) to reach the heat balance of input and output. The calculation formula is shown as follows ${ }^{[3]}$ :

A Heat input

Heat supply of natural gas $\mathrm{Q}_{1}$

$$
\mathrm{Q}_{1}=\mathrm{BQ}_{\mathrm{DW}}^{\mathrm{S}} \quad k J / h
$$

B Heat output

1) Calorific requirement $\mathrm{Q}_{1}$ of heating materials

$$
\mathrm{Q}_{1}^{\prime}=G_{\mathrm{P}}\left(\mathrm{C}_{1}^{\prime} \mathrm{t}_{1}^{\prime}-\mathrm{C}_{1 \mathrm{e}}{ }^{\prime} \mathrm{t}_{\mathrm{e}}\right) \quad k J / h
$$

2) Calorific requirement $\mathrm{Q}_{2}$ ' of charging basket heat mix

$$
\mathrm{Q}_{2}^{\prime}=G_{2}\left(\mathrm{C}_{2}{ }^{\prime} \mathrm{t}_{1}{ }^{\prime}-\mathrm{C}_{2 \mathrm{e}}{ }^{\prime} \mathrm{t}_{\mathrm{e}}\right) \quad k J / h
$$

3) Heat $\mathrm{Q}_{3}$, of exhaust emission

$$
\mathrm{Q}_{3}{ }^{\prime}=\mathrm{B} V_{n}^{S}\left(\mathrm{C}_{3}{ }^{\prime} \mathrm{t}_{3}{ }^{\prime}-\mathrm{C}_{3 \mathrm{e}}{ }^{\prime} \mathrm{t}_{\mathrm{e}}\right) \quad k J / h
$$

4) Heat release $\mathrm{Q}_{4}{ }^{\prime}$ of furnace wall

$$
\mathrm{Q}_{4}^{\prime}=F^{\prime} * 4.18\left\{4.88 \varepsilon\left[\left(\frac{273+t_{b}}{100}\right)^{4}-\left(\frac{273+t_{e}}{100}\right)^{4}\right]+A\left(t_{b}-t_{e}\right)^{1.25}\right\} \quad k J / h
$$


5) Other heat losses $\mathrm{Q}_{5}$

Estimated based on $5 \%$ of heat input

In the above formula: B is natural gas consumption of solid smelting oven (or aging oven) per hour, $\mathrm{Nm}^{3} / \mathrm{h} ; \mathrm{Q}_{\mathrm{DW}}^{\mathrm{S}}$ is lower heating value of natural gas (calculated based on $35588 \mathrm{~kJ} / \mathrm{Nm}^{3}$ ); $\mathrm{G}_{\mathrm{P}}$ is the output of heat treatment products per hour, $\mathrm{kg} / \mathrm{h} ; \mathrm{G}_{2}$ is the weight of charging basket needed by the output per hour, $\mathrm{kg} / \mathrm{h} ; \mathrm{C}$ is the average specific heat of each substance at the corresponding temperature, $\mathrm{kJ} /\left(\mathrm{kg} .{ }^{\circ} \mathrm{C}\right)$ or $\mathrm{kJ} /\left(\mathrm{Nm}^{3} .{ }^{\circ} \mathrm{C}\right) ; V_{n}^{S}$ is the smoke volume generated by burning of natural gas per cubic meter, $\mathrm{Nm}^{3} / \mathrm{Nm}^{3} ; \mathrm{F}$ is heat radiating area of external furnace wall, $\mathrm{m}^{2} ; \mathrm{t}$ is the temperature of each material or waste gas, of which, the subscripted $b$ is average heat radiating area of external furnace wall, ${ }^{\circ} \mathrm{C}$. The above-mentioned parameters can be obtained from design requirements of solid smelting oven (or aging oven) and physical property parameters of materials when heat balance is calculated. Natural gas consumption is unknown in the heat balance formula and can be obtained from cut-and-try calculation results. Natural gas consumption of solid smelting oven per hour and of aging oven per hour is respectively $39.85 \mathrm{Nm}^{3} / \mathrm{h}$ and $6.86 \mathrm{Nm}^{3} / \mathrm{h}$. The specific heat balance table can be seen as follows:

Table 2 Heat balance table of solid smelting oven

\begin{tabular}{|c|c|c|c|c|c|c|c|}
\hline \multirow{2}{*}{ No. } & \multirow{2}{*}{ Heat input } & \multicolumn{2}{|c|}{ Heat } & \multirow{2}{*}{ No. } & \multirow{2}{*}{ Heat output } & \multicolumn{2}{|c|}{ Heat } \\
\hline & & $(\mathbf{M J} / \mathbf{h})$ & $(\%)$ & & & $(\mathbf{M J} / \mathbf{h})$ & $(\%)$ \\
\hline \multirow[t]{5}{*}{$\mathrm{Q}_{1}$} & $\begin{array}{l}\text { Heat supply } \\
\text { of natural gas }\end{array}$ & 1418.2 & 100 & $\mathrm{Q}^{\prime}$ & $\begin{array}{l}\text { Calorific requirement of } \\
\text { heating materials }\end{array}$ & 619.3 & 43.7 \\
\hline & & & & $\mathrm{Q}_{2}^{\prime}$ & $\begin{array}{l}\text { Calorific requirement of } \\
\text { charging basket heat mix }\end{array}$ & 336.6 & 23.7 \\
\hline & & & & $\mathrm{Q}_{3}{ }^{\prime}$ & Heat of exhaust emission & 324.2 & 22.9 \\
\hline & & & & $\mathrm{Q}_{4}{ }^{\prime}$ & Heat release of furnace wall & 67.2 & 4.7 \\
\hline & & & & $\mathrm{Q}_{5}{ }^{\prime}$ & Other heat losses & 70.9 & 5.0 \\
\hline$\sum \mathrm{Q}$ & Total & 1418.2 & 100 & $\sum Q^{\prime}$ & Total & 1418.2 & 100.0 \\
\hline
\end{tabular}

Table 3 Heat balance table of aging oven

\begin{tabular}{|c|c|c|c|c|c|c|c|}
\hline \multirow{2}{*}{ No. } & \multirow{2}{*}{ Heat input } & \multicolumn{2}{|c|}{ Heat } & \multirow{2}{*}{ No. } & \multirow{2}{*}{ Heat output } & \multicolumn{2}{|c|}{ Heat } \\
\hline & & $(\mathbf{M J} / \mathbf{h})$ & $(\%)$ & & & $(\mathbf{M J} / \mathbf{h})$ & $(\%)$ \\
\hline \multirow[t]{5}{*}{$\mathrm{Q}_{1}$} & $\begin{array}{l}\text { Heat supply } \\
\text { of natural gas }\end{array}$ & 244.1 & 100 & $\mathrm{Q}_{1}{ }^{\prime}$ & $\begin{array}{l}\text { Calorific requirement of } \\
\text { heating materials }\end{array}$ & 121.4 & 49.7 \\
\hline & & & & $\mathrm{Q}_{2}{ }^{\prime}$ & $\begin{array}{l}\text { Calorific requirement of } \\
\text { charging basket heat mix }\end{array}$ & 70.0 & 28.7 \\
\hline & & & & $\mathrm{Q}_{3^{\prime}}$ & Heat of exhaust emission & 11.1 & 4.5 \\
\hline & & & & $\mathrm{Q}_{4}{ }^{\prime}$ & Heat release of furnace wall & 29.4 & 12.0 \\
\hline & & & & $\mathrm{Q}_{5}{ }^{\prime}$ & Other heat losses & 12.2 & 5 \\
\hline$\sum \mathrm{Q}$ & Total & 244.1 & 100 & $\sum Q^{\prime}$ & Total & 244.1 & 100 \\
\hline
\end{tabular}

According to the results in Table 2 , the heat which is supplied to aging oven is $324.2 *(1-5 \%)=308 \mathrm{MJ} / \mathrm{h}$ and surplus rate of waste heat is $20.7 \%$ when heat emitted from waste gas of solid smelting deducts heat loss of waste gas running piping (calculated based on total residual heat). Thus it can be seen heat supply of aging oven can be fully satisfied and can't be normally supplemented by natural gas. 


\section{Economic Benefit Analysis}

After being calculated, natural gas consumption of solid smelting oven and aging per hour is respectively $39.85 \mathrm{Nm}^{3} / \mathrm{h}$ and $6.86 \mathrm{Nm}^{3} / \mathrm{h}$. When waste gas heat of solid smelting oven supplies heat in place of natural gas of aging oven, the economizing ratio is up to $14.7 \%$, and $49000 \mathrm{Nm}^{3}$ of natural gas can be saved in the heat treatment procedure year (calculated based on $7200 \mathrm{~h}$ per year). The cost of natural gas - RMB 207,000 can be saved per year when unit price of industrial gas is RMB $4.2 / \mathrm{Nm}^{3}$.

In the energy saving reconstruction of heat treatment procedure, $22 \mathrm{~m}$ of external thermal insulation waste gas transmission pipeline, two sets of control valves, two sets of temperature sensors, control system and engineering cost shall be added, which total RMB 100,000.

After calculation: project reconstruction payback period is $10 / 20.7=0.48$ year (six months). The project with payback period less than one year shall be preferred because of high investment value.

\section{Conclusion}

As the equipment operation synchronous rate of two ovens is high, when waste gas heat of solid smelting oven supplies heat in place of aging oven, investment value is high, economizing ratio of heat treatment procedure can be up to $14.7 \%$ and $107 \mathrm{t}$ of carbon emission can be reduced. Meanwhile, for waste heat of the procedure, two ovens can be further used as recycling spaces of heating domestic water, so they shall be designed rationally and optimized. This project can guide and demonstrate the energy saving reconstruction in the current heat treatment procedure of aluminum alloy castings.

\section{References}

[1]. Xu Lihua and Qian Huiguo, Energy Saving and Emission Reduction Technology of Plasterboard Drying Room, Energy Research and Information, 2015(2), p106-108

[2]. Technical Specification of SHEOI Industrial Combustion Equipment (Shanghai) Co., Ltd.,2016

[3]. Temporary Provisions on Ten Furnace and Kiln Heat Balance Test Methods of Ministry of Metallurgical Industry,1983 